\title{
Efektivitas Kombinasi Ekstrak Etanol Daun Bunga Matahari (Helianthus annuus) dan Tanaman Anting-Anting (Acalypha indica Linn) sebagai Antimalaria Secara In Vivo
}

\author{
(Effectiveness of Ethanol Extract Combinations of Sunflower (Helianthus annuus) Leaves \\ and Anting-anting (Acalypha indica Linn) as In Vivo Antimalarial)
}

\begin{abstract}
Khoirul Ngibad
Jurusan Teknologi Laboratorium Medik, Fakultas Ilmu Kesehatan, Universitas Maarif Hasyim Latif, Sidoarjo, Indonesia, 61257
\end{abstract}

Article Info:

Received: 28 January 2019

in revised form: 17 February 2019

Accepted: 18 March 2019

Available Online: 20 March 2019

\section{Keywords:}

Sunflower

Helianthus annuus

Anting-anting

Acalypha indica Linn,

Antimalarial

Corresponding Author:

Khoirul Ngibad

Jurusan Teknologi Laboratorium Medik

Fakultas Ilmu Kesehatan,

Universitas Maarif Hasyim Latif Sidoarjo,

61257, Indonesia

Mobile : 085746466594

Email:khoirul_ngibad@dosen.umaha.ac.id

\begin{abstract}
Sunflower (Helianthus annuus) and anting-anting (Acalypha indica Linn), can be studied as efficacious malaria medicinal plants for preventing the development of malaria plasmodium resistance. This study aims to determine the effectiveness of the combination of $80 \%$ ethanol extract of sunflower leaves and anting-anting as antimalarials. This study included extraction of sunflower leaves and anting-anting plant separately using the maceration method for 24 hours with $80 \%$ ethanol. Stirring is aided by a 3 hour shaker and then the obtained extracts were mixed and tested in vivo antimalarial activity against mice test animals. Data of the parasitemia degree was analyzed for the determination of Effective Dose $\left(\mathrm{ED}_{50}\right)$ using probit analysis then determination of Combination Index (CI) value. The results of the antimalarial activity test on tested mice were $\mathrm{ED}_{50}$ of $1.23 \mathrm{mg} / \mathrm{kg}$ human body with a Combination Index (CI) of 0.46 (CI <1) which means synergistic potency.
\end{abstract}




\begin{abstract}
ABSTRAK
Tanaman bunga Matahari dan Anting-anting bisa diteliti sebagai tanaman yang berkhasiat sebagai tanaman obat malaria dengan harapan dapat mencegah berkembangnya resistensi plasmodium malaria. Penelitian ini bertujuan untuk mempelajari efektivitas kombinasi ekstrak etanol $80 \%$ daun bunga Matahari dan tanaman Anting-anting sebagai antimalaria. Ekstraksi daun bunga Matahari dan tanaman Anting-anting dilakukan secara terpisah menggunakan metode maserasi dengan pelarut etanol $80 \%$ disertai pengadukan dengan shaker. Selanjutnya, ekstrak dicampur dan diuji aktivitas antimalaria secara in vivo menggunakan hewan uji coba mencit. Data derajat parasitemia dianalisis untuk penentuan Efectivitas Dosis $\left(\mathrm{ED}_{50}\right)$ menggunakan analisis probit selanjutnya ditentukan nilai Combination Index (CI). Hasil uji aktivitas antimalaria terhadap hewan uji mencit didapatkan $\mathrm{ED}_{50}$ sebesar 1,23 mg/kg BB manusia dengan nilai Combination Index (CI) sebesar 0,46 (CI < 1) yang berarti potensinya bersifat sinergis.
\end{abstract}

Kata Kunci : Bunga Matahari, Helianthus annuus, Anting-anting, Acalypha indica Linn, Antimalaria

\section{PENDAHULUAN}

Malaria merupakan salah satu penyakit infeksi yang sampai kini masih menjadi masalah kesehatan yang serius dan kompleks. Penyakit ini disebabkan adanya infeksi sel darah merah manusia melalui nyamuk Anopheles betina oleh empat jenis spesies parasit Plasmodium ( $P$. falciparum, $P$. vivax, $P$. ovale dan $P$. malariae) (Husin, 2007). Semakin meningkatnya resistensi (kekebalan) Plasmodium falciparum terhadap obat antimalaria mengakibatkan terjadinya peningkatan jumlah penderita penyakit malaria. Penyebab utama terjadinya resistensi dikarenakan adanya parasit malaria yang mengalami mutasi genetik secara alami sehingga parasit tetap dapat bertahan hidup (Rosenthal, 2003).

Terapi penyakit malaria yang disarankan adalah terapi kombinasi kedua atau lebih obat antimalaria yang masing-masing bekerja membunuh parasit di daerah skizontosidal pada target reseptor yang berbeda dengan harapan dapat mencegah atau menghambat berkembangnya resistensi (Sukandar, Andrajati, Sigit, Adnyana, \& Setiadi, n.d.). Hal tersebut memberikan peluang untuk mengkombinasikan antara ekstrak dua tanaman dari bahan alam yang dimungkinkan dapat menimbulkan efek sinergis sebagai antimalaria. Kombinasi ektrak dua tanaman didasarkan oleh adanya efek aditif dan sinergis dari penggunaan obat campuran serta didukung oleh rekomendasi WHO untuk mengkombinasikan obat-obat malaria. Efek aditif terjadi apabila kedua obat atau lebih yang memiliki kerja yang serupa atau tidak serupa diberikan, maka kombinasi dari kedua obat itu menjadi aditif (efek dua kali lipat atau jumlah dari kedua obat) (Kee, Hayes, \& McCuistion, 1993).

Kombinasi antara tanaman bunga Matahari (Helianthus annuus) dan Anting-anting (Acalypha indica Linn) diduga dapat menimbulkan efek sinergis sebagai antimalaria. Hal ini didukung oleh penelitian tentang daun bunga Matahari yang diekstraksi dengan diklorometana mengandung senyawa seskuiterpen lakton (Susilawati, Matsjeh, Pranowo, \& Anwar, 2015). Ekstrak diklorometana daun bunga Matahari mampu membunuh parasit Plasmodium berghei baik pada dosis 5, 50, $500 \mathrm{mg} / \mathrm{kg} \mathrm{BB}$ dan pada masing-masing dosis tersebut telah diketahui bahwa derajat parasitemia mencapai $0 \%$ pada hari ke-3 dan ke-4 pasca terapi. Tanaman Anting-anting juga dapat berpotensi sebagai antimalaria. Kandungan ekstrak kasar etil asetat tanaman Acalypha indica Linn yang dapat menghasilkan persen penghambatan pertumbuhan parasit secara in vivo pada hari ke-7 sebesar 85,74\% untuk dosis 1 $\mathrm{mg} / \mathrm{kg} \mathrm{BB}$; 86,08 \% untuk dosis $10 \mathrm{mg} / \mathrm{kg} \mathrm{BB;} \mathrm{87,78}$ $\%$ untuk dosis $100 \mathrm{mg} / \mathrm{kg}$ BB (Muti'ah, Elok \& Ijro'atul, 2012).

Senyawa alkaloid berberine dan menisperine telah diketahui dapat menghambat transport kolin pada biosintesis phospatidilkolin untuk membentuk membran parasit baru sehingga menyebabkan kegagalan terbentuknya parasit baru. Senyawa kolin dibutuhkan untuk proses biosintesis fospolipid dalam 
pembentukan membran parasit (Muti'ah \& Elok, 2013). Seskuiterpen lakton yang merupakan senyawa aktif antimalaria dari daun bunga Matahari diduga mempunyai potensi efek yang sinergis dengan alkaloid berberine dan menisperine yang merupakan senyawa aktif antimalaria dari tanaman Anting-anting dimana kedua golongan senyawa tersebut telah diketahui bekerja membunuh parasit di daerah skizontosidal pada target reseptor yang berbeda sehingga kombinasi tersebut dapat mencegah atau menghambat berkembangnya resistensi. Hal inilah yang mendorong penelitian ini untuk dilakukan.

Dalam penelitian ini, akan digunakan serbuk sampel kering daun Helianthus annuus dan Acalypha indica Linn. Pemisahan senyawa metabolit sekunder dilakukan menggunakan metode maserasi dengan etanol $80 \%$ untuk dilakukan uji antimalaria secara in vivo pada hewan uji coba mencit dengan kombinasi ektrak etanol $80 \%$ daun bunga Matahari dan tanaman Anting-anting masing-masing menggunakan berbagai variasi dosis bertingkat (0.05; 0.5; 5 dan 50 $\mathrm{mg} / \mathrm{kg} \mathrm{BB}$ ) dengan perbandingan $1: 1$.

\section{METODE PENELITIAN Alat dan Bahan}

Alat-alat yang digunakan antara lain : perangkat alat gelas, blender,neraca analitik, kertas saring whatman, shaker, penyaring buchner, oven, vial, ayakan 60 mesh, rotary evaporator, bejana untuk proses pengaliran gas $\mathrm{N}_{2}$, krus porselen, piknometer $25 \mathrm{~mL}$, hair dryer, tanur, desikator, destilator, kandang mencit, botol minum mencit, kawat dan tempat makan, vacum tube, Laminer air flow vertical, centrifuge, botol biakan (culture flask) $50 \mathrm{~mL}$, pinset, mikropipet, mikroskop, gunting, spuit $1 \mathrm{~mL}$, laboratory bottle $100 \mathrm{~mL}$, object glass, Nitrogen liquid tank, pipet disposible $2 \mathrm{~mL}$, tabung flakon 15 mL. mikropipet, yellow tip, pinset, spuit $1 \mathrm{~mL}$. Alat untuk mengambil darah antara lain: gunting steril, jarum pentul, kapas, spuit $1 \mathrm{~mL}$. Alat untuk mengukur derajat parasitemia antara lain: object glass, mikroskop dan pipet. Alat yang diperlukan untuk perlakuan terapi antara lain: vials $15 \mathrm{~mL}$, alat suntik dan spuit $1 \mathrm{~mL}$.

Bahan-bahan penelitian meliputi : daun bunga Matahari yang diambil dari daerah Punten, desa Sido Mulyo Kota Batu dan tanaman Anting-anting yang diperoleh dari daerah Krebet, Sregat, Kabupaten Blitar, etanol $80 \%$, gas $\mathrm{N}_{2}$, mencit putih jantan
Balb/C, makanan mencit, serbuk gergaji, darah yang diambil dari ekor mencit, buffer Giemsa, Giemsa fluka, dan metanol p.a., dan CMC-Na $1 \%$.

\section{Metode}

\section{Ekstraksi}

Serbuk kedua sampel diperlukan secara terpisah. Masing-masing ditimbang sebanyak 100 g dan perlakuan dibagi ke dalam 2 bagian masing-masing $50 \mathrm{~g}$ untuk proses maserasi. Kemudian masingmasing diekstraksi maserasi menggunakan $250 \mathrm{~mL}$ etanol $80 \%$ selama 1 hari dengan pengocokan selama 3 jam memakai shaker berkecepatan 120 rpm. Kemudian disaring menjadi filtrat dan ampas. Masing-masing filtrat digabung dan dipekatkan dengan rotary evaporator sampai diperoleh ekstrak pekat. Kemudian dialiri dengan gas $\mathrm{N}_{2}$ dengan tujuan untuk menghilangkan sisa-sisa pelarut dan ditentukan rendemen masing-masing ekstrak kasar (Ngibad, 2018). Selanjutnya masing-masing ekstrak etanol pekat dari keduasampel yangdiperoleh dikombinasi dengan perbandingan 1:1 untuk dilakukan uji antimalaria secara in vivo pada tubuh mencit jantan.

\section{Uji Antimalaria Kombinasi Ektrak Etanol 80 \% Perlakuan Hewan Coba}

Penelitian ini menggunakan hewan coba mencit (Mus musculus) galur Balb/C jantan, umur 8 - 10 minggu, berat badan 20 - 25 g. Ketentuan dari tiap-tiap kelompok adalah sebagai berikut:

1. Kelompok kontrol (-) adalah kelompok perlakuan tanpa infeksi $P$. berghei dengan pemberian 0,5 $\mathrm{mL}$ CMC-Na $1 \%$ secara per-oral.

2. Kelompok kontrol $(+)$ adalah kelompok yang diinfeksi dengan $P$. berghei dengan pemberian 0,5 $\mathrm{mL}$ CMC-Na $1 \%$ secara per-oral.

3. Kelompok Klorokuin adalah kelompok perlakuan infeksi $P$. berghei dengan dosis 5,71 $\mathrm{mg} / \mathrm{kg} \mathrm{BB}$ sekali sehari secara per-oral.

4. Kelompok 1 adalah kelompok perlakuan infeksi $P$. berghei dan terapi kombinasi ekstrak etanol 80 \% daun bunga Matahari dan tanaman Antinganting masing-masing dengan dosis $0,05 \mathrm{mg} / \mathrm{kg}$ BB sekali sehari secara per-oral.

5. Kelompok 2 adalah kelompok perlakuan infeksi $P$. berghei dan terapi kombinasi ekstrak etanol 80 $\%$ daun bunga Matahari dan tanaman Antinganting masing-masing dengan dosis $0,5 \mathrm{mg} / \mathrm{kg} \mathrm{BB}$ sekali sehari secara per-oral. 
6. Kelompok 3 adalah kelompok perlakuan infeksi $P$. berghei dan terapi kombinasi ekstrak etanol 80 $\%$ daun bunga Matahari dan tanaman Antinganting masing-masing dengan dosis $5 \mathrm{mg} / \mathrm{kg} \mathrm{BB}$ sekali sehari secara per-oral.

7. Kelompok 4 adalah kelompok perlakuan infeksi $P$. berghei dan terapi kombinasi ekstrak etanol 80 \% daun bunga Matahari dan tanaman Antinganting masing-masing dengan dosis $50 \mathrm{mg} / \mathrm{kg} \mathrm{BB}$ sekali sehari secara per-oral.

Uji aktivitas antimalarial secara in vivo menggunakan metode Peter (Muti'ah \& Elok, 2013). Terapi dilakukan ketika derajat parasitemia setelah infeksi mencapai $1-5 \%$ yang dihitung sebagai hari ke-0. Terapi dilakukan setiap hari selama 4 hari. Pengamatan derajat parasitemia dilakukan setiap hari mulai hari ke-0, hari ke-1, hari ke-2, hari ke-3 dan hari ke-4.

\section{Freezing dan Thawing Isolat $P$. berghei}

Darah jantung diambil sebanyak 0,8 $\mathrm{mL}$ dari mencit donor yang telah terinfeksi kemudian dimasukkan dalam vacum tube yang telah berisi EDTA. Selanjutnya, ditambahkan dengan 1,6 mL larutan Alsever's yang mengandung $10 \%$ gliserol. Kemudian, vacum tube ditutup dan dimasukkan ke dalam liquid nitrogen tank selama \pm 1 menit. Setelah itu, dipindahkan ke dalam freezer $-70{ }^{\circ} \mathrm{C}$ sehingga parasit memungkinkan untuk mencair dan siap untuk diinfeksikan pada hewan coba (Coutrier, 2008).

\section{Inokulasi P. berghei}

Inokulasi $P$. berghei dilakukan secara intraperitonial (i.p) dengan jumlah parasit yang diinfeksikan sebanyak $1 \times 10^{6}$. Dalam hal pemeriksaan mencit yang telah terinfeksi parasit ini, diasumsikan pada mencit yang normal nilai hematrokritnya (angka yang menunjukkan prosentase zat padat dalam darah terhadap cairan darah) adalah $60 \%$ dan disini mencit donor memiliki $6 \times 10^{9}$ sel darah merah/mL dalam darah. Setelah dilakukan infeksi selanjutnya dilakukan pengamatan parasitemia setiap hari hingga parasitemia mencapai $1-5 \%$ sebagai hari ke-0 terapi. Kemudian dilakukan terapi obat atau ekstrak uji sampai pada hari ke-4 (Widawati, 2013).

\section{Pengukuran Derajat Parasitemia}

Sedangkan persen penghambatan pertumbuhan parasit dihitung dengan rumus sebagai berikut:

$\%$ penghambatan $=\frac{\% \text { derajat parasitemia kontrol positif }-\% \text { derajat parasitemia obat }}{\% \text { derajat parasitemia kontrol positif }} \times 100 \%$

Selanjutnya ditentukan harga $\mathrm{ED}_{50}$ dengan menggunakan analisis probit dari \% penghambatan hari ke-4.

\section{Analisis Data}

Data yang diperoleh dibuat dalam bentuk tabel dan grafik, kemudian dideskripsikan hasilnya. Tingkat efektivitas kombinasi ekstrak terhadap pertumbuhan P.berghei dalam tubuh mencit dapat diketahui dengan melakukan uji $\mathrm{ED}_{50}$ menggunakan analisis probit pada program Excel. Selanjutnya untuk mengetahui daya efektivitas ekstrak dalam menghambat pertumbuhan parasit Plasmodium berghei dapat diketahui selain dari nilai persen penghambatan juga dapat diketahui berdasarkan hasil analisis statistika data derajat parasitemia menggunakan program SPSS 16.00 dengan Uji OneWay ANOVA. Selanjutnya untuk mengetahui signifikasi perbedaan setiap kelompok perlakuan pada masing-masing hari dilakukan uji perbandingan berganda Tukey. Dan kemudian untuk mengetahui hubungan antara pengaruh dosis terhadap persen penghambatan pertumbuhan parasit Plasmodium berghei maka dilakukan uji korelasi dosis.

\section{HASIL DAN PEMBAHASAN Ekstraksi}

Berdasarkan Tabel 1 dan 2 dapat diketahui bahwa rendemen ekstrak pekat etanol $80 \%$ daun bunga Matahari dan tanaman Anting-anting masing-masing sebesar 21,76 \% dan23 \%. Hasil ekstrak pekat yang diperoleh selanjutnya digunakan untuk uji selanjutnya yaitu uji antimalaria secara in vivo kombinasi ektrak etanol 80 \% dengan penentuan Efectivitas Dosis (ED) ${ }_{50}$.

Tabel 1. Hasil maserasi serbuk daun bunga Matahari

\begin{tabular}{ccccc}
\hline Pelarut & $\begin{array}{c}\text { Warna } \\
\text { ekstrak } \\
\text { pekat }\end{array}$ & $\begin{array}{c}\text { Berat } \\
\text { sampel } \\
\text { (g) }\end{array}$ & $\begin{array}{c}\text { Berat } \\
\text { ekstrak } \\
\text { pekat } \\
\text { (g) }\end{array}$ & $\begin{array}{c}\text { Rendemen } \\
(\mathbf{\%})(\mathbf{b} / \mathbf{b})\end{array}$ \\
\hline $\begin{array}{c}\text { Etanol } \\
80 \%\end{array}$ & $\begin{array}{c}\text { Hijau } \\
\text { tua }\end{array}$ & 100 & 21,76 & 21,76 \\
\hline
\end{tabular}


Tabel 2. Hasil maserasi serbuk tanaman Antinganting

\begin{tabular}{ccccc}
\hline Pelarut & $\begin{array}{c}\text { Warna } \\
\text { ekstrak } \\
\text { pekat }\end{array}$ & $\begin{array}{c}\text { Berat } \\
\text { sampel } \\
\text { (g) }\end{array}$ & $\begin{array}{c}\text { Berat } \\
\text { ekstrak } \\
\text { pekat (g) }\end{array}$ & $\begin{array}{c}\text { Rendemen } \\
\text { (\%) (b/b) }\end{array}$ \\
\hline $\begin{array}{c}\text { Etanol } \\
80 \%\end{array}$ & $\begin{array}{c}\text { Hijau tua } \\
\text { kecoklata } \\
\text { n }\end{array}$ & 100 & 23 & 23 \\
\hline
\end{tabular}

\section{Uji Antimalaria Kombinasi Ektrak Etanol 80 \%}

Tabel 3 dan Gambar 1 menunjukkan bahwa rata-rata derajat parasitemia semua perlakuan pada hari ke-0 adalah sebesar $1-3 \%$. Selain itu, diketahui bahwa hasil rata-rata derajat parasitemia hari ke-1, sampai hari ke-4 untuk semua kelompok perlakuan terapi kombinasi ekstrak lebih rendah dibandingkan kelompok kontrol positif. Diketahui pula bahwa pada hari ke-3 dan ke-4 pasca terapi seiring dengan peningkatan dosis terjadi penurunan rata-rata derajat parasitemia. Kemudian nilai standar deviasi yang diperoleh menunjukkan ukuran sebaran statistik (mengukur bagaimana nilai-nilai data persen derajat parasitemia tersebar). Semakin tinggi nilai standar deviasi, maka tingkat error data semakin banyak.

Tabel 3. Rata-rata derajat parasitemia serta standar deviasi kombinasi ekstrak

\begin{tabular}{cccccc}
\hline \multirow{2}{*}{$\begin{array}{c}\text { Kelompok } \\
\text { perlakuan }\end{array}$} & \multicolumn{5}{c}{ Herata derajat parasitemia (\% ) \pm Standar Deviasi } \\
\cline { 2 - 6 } Hont & Hari ke-1 & Hari ke-2 & Hari ke-3 & Hari ke-4 \\
\hline Kontrol positif & $1,39 \pm 0,34$ & $3,60 \pm 1,41$ & $4,17 \pm 1,71$ & $5 \pm 1,47$ & $5,20 \pm 1,17$ \\
Klorokuin & $2,75 \pm 0,82$ & $1,38 \pm 0,30$ & $1,28 \pm 0,34$ & $0,35 \pm 0,29$ & $0 \pm 0,00$ \\
AM 1 & $2,1 \pm 0,55$ & $2,57 \pm 0,68$ & $3,57 \pm 0,41$ & $3,55 \pm 0,55$ & $2,90 \pm 0,55$ \\
AM 2 & $2,38 \pm 0,74$ & $2,83 \pm 0,61$ & $3,07 \pm 0,79$ & $2,87 \pm 0,79$ & $2,70 \pm 0,55$ \\
AM 3 & $2,47 \pm 0,69$ & $3,07 \pm 0,80$ & $3,25 \pm 0,71$ & $2,82 \pm 0,66$ & $2,52 \pm 0,59$ \\
AM 4 & $2,37 \pm 0,80$ & $2,63 \pm 0,67$ & $3,20 \pm 0,62$ & $2,28 \pm 0,63$ & $1,63 \pm 0,59$ \\
\hline
\end{tabular}

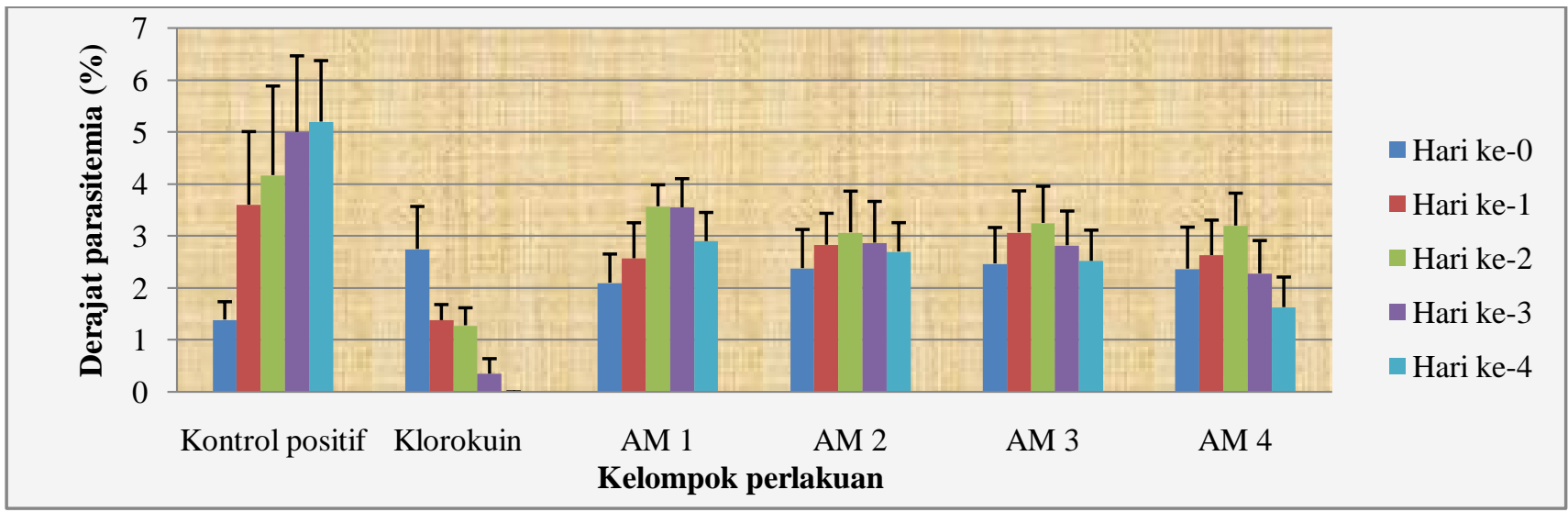

Gambar 1. Grafik derajat parasitemia kelompok perlakuan kombinasi ekstrak terhadap kontrol positif

Keterangan:

Kontrol positif $\quad$ : infeksi $P$. berghei tanpa terapi

Klorokuin : pemberian Klorokuin 5,71 mg/kg BB

AM 1 : pemberian terapi ekstrak daun bunga Matahari dosis 0,05 mg/kg BB dan Anting-anting dosis $0,05 \mathrm{mg} / \mathrm{kg} \mathrm{BB}$

AM 2 : pemberian terapi ekstrak daun bunga Matahari dosis 0,5 mg/kg BB dan Anting-anting dosis $0,5 \mathrm{mg} / \mathrm{kg} \mathrm{BB}$

AM 3 : pemberian terapi ekstrak daun bunga Matahari dosis $5 \mathrm{mg} / \mathrm{kg}$ BB dan Anting-anting dosis 5 $\mathrm{mg} / \mathrm{kg} \mathrm{BB}$

AM 4 : pemberian terapi ekstrak daun bunga Matahari dosis $50 \mathrm{mg} / \mathrm{kg}$ BB dan Anting-anting dosis 50 $\mathrm{mg} / \mathrm{kg} \mathrm{BB}$ 
“Derajat parasitemia kontrol positif” diperoleh dari rata-rata derajat parasitemia kelompok perlakuan yang diinfeksi Plasmodium berghei tanpa perlakuan terapi kombinasi ekstrak. "Derajat parasitemia obat" diperoleh dari derajat parasitemia kelompok perlakuan yang diinfeksi Plasmodium berghei dan diterapi kombinasi ekstrak. Hasil perhitungan persentase penghambatan pertumbuhan parasit ratarata dari kombinasi ekstrak pada hari ke-4 pasca terapi disajikan dalam Tabel 4.

Tabel 4. Persen penghambatan pertumbuhan parasit rata-rata kombinasi ekstrak hari ke-4

\begin{tabular}{cc}
\hline $\begin{array}{c}\text { Dosis (mg/kg } \\
\text { BB) }\end{array}$ & $\begin{array}{c}\text { Persen penghambatan } \\
\text { pertumbuhan parasit }\end{array}$ \\
\hline 0,1 & $44,23 \%$ \\
1 & $48,00 \%$ \\
10 & $51,50 \%$ \\
100 & $68,65 \%$ \\
\hline
\end{tabular}

Penentuan dosis efektif $50 \%\left(\mathrm{ED}_{50}\right)$ pada penelitian ini digunakan analisis probit \%penghambatan pertumbuhan parasit selama 4 hari kemudian dilanjutkan dengan analisis regresi linier dengan program Microsoft Office Excel. Alasan dipilihnya analisis probit karena hubungan repon terhadap dosis secara alami bersifat sigmoid (Vincent, 2008). Dengan demikian kurva yang diperoleh antara hubungan respon dengan dosis merupakan kurva dosis-respon yang bersifat sigmoid. Dari kurva yang dihasilkan diperoleh persamaan $\mathrm{y}=0,201 \mathrm{x}+4,982$, dengan nilai $\mathrm{R}^{2}$ sebesar $\mathrm{R}^{2}=0,843$, dimana $\mathrm{R}^{2}$ merupakan koefisien determinasi log dosis terhadap probit penghambatan pertumbuhan parasit. Nilai $\mathrm{ED}_{50}$ ditentukan dengan cara memasukkan nilai penghambatan $50 \%$ yang telah ditransformasikan dalam bentuk probit yaitu sebesar 5 pada persamaan 0,201x + 4,982 dan diperoleh nilai $\mathrm{ED}_{50}$ sebesar 1,23 $\mathrm{mg} / \mathrm{kg}$ BB manusia.

Nilai perhitungan yang diperoleh tersebut merupakan $\mathrm{ED}_{50}$ (efektif dosis $50 \%$ ) adalah sebesar $1,23 \mathrm{mg} / \mathrm{kg}$ BB manusia. Jadi dapat dikatakan bahwa $1,23 \mathrm{mg} / \mathrm{kg}$ BB manusia merupakan dosis yang diperlukan agar menghasilkan efek terapi pada $50 \%$ populasi parasit dalam tubuh hewan uji. Efektivitas kombinasi ekstrak dapat diperjelas juga dari kemampuan hidup mencit selama hari perlakuan dan pasca perlakuan $( \pm 23$ hari), dimana kemampuan hidup hewan coba kelompok kontrol positif adalah lebih pendek daripada kelompok perlakuan dosis kombinasi.

Kombinasi ekstrak dalam penelitian ini menghasilkan nilai $\mathrm{ED}_{50}$ yang lebih kecil apabila dibandingkan dengan hasil ekstrak etanol $80 \%$ daun bunga Matahari didapatkan $\mathrm{ED}_{50}$ sebesar 4,64 mg/kg BB sedangkan hasil ekstrak etanol $80 \%$ tanaman Antinganting dihasilkan $\mathrm{ED}_{50}$ sebesar 6,32 mg/kg BB. Hasil $\mathrm{ED}_{50}$ yang didapatkan kurang dari $10 \mathrm{mg} / \mathrm{kg}$ yang artinya menurut Herintsoa et al. (2010) menunjukkan aktivitas antiplasmodial yang sangat bagus (Herintsoa et al., 2005).

Kombinasi ekstrak dapat diketahui dengan menghitung nilai Combination Index (CI) dengan rumus sebagai berikut (Chou, 2006) :

$$
\text { Combination Index }(\mathrm{CI})=\frac{(\mathrm{D}) 1}{(\mathrm{Dx}) 1}+\frac{(\mathrm{D}) 2}{(\mathrm{Dx}) 2}
$$

Kombinasi ekstrak dalam penelitian ini menghasilkan hubungan yang sinergis. Hal ini dapat diketahui dengan hasil Combination Index (CI) sebesar 0,46.

Efek penghambatan pertumbuhan Plasmodium berghei juga dapat diketahui berdasarkan nilai persen penghambatan yang diperoleh, seperti yang disajikan dalam Tabel 4. Selain itu, efek penghambatan juga dapat diketahui dari hasil analisis statistika data derajat parasitemia menggunakan program SPSS 16.00 dengan Uji OneWay ANOVA. Uji OneWay ANOVA digunakan untuk mengetahui signifikasi rata-rata derajat parasitemia perlakuan terhadap kontrol. Selanjutnya untuk mengetahui signifikasi perbedaan tiap-tiap kelompok perlakuan dilakukan Uji Tukey.

Untuk mengetahui ada tidaknya perbedaan rata-rata derajat parasitemia antar perlakuan pada masingmasing hari (hari ke-1, hari ke-2, hari ke-3, dan hari ke-4) digunakan uji perbandingan berganda Tukey seperti yang disajikan pada Tabel 5 . 
Tabel 5. Hasil uji Tukey derajat parasitemia hari ke-4

\begin{tabular}{cccc}
\hline $\begin{array}{c}\text { Kelompok } \\
\text { perlakuan }\end{array}$ & $\begin{array}{c}\text { Dibandingkan dengan } \\
\text { kelompok perlakuan }\end{array}$ & Nilai p & Makna \\
\hline \multirow{5}{*}{ Kontrol positif } & Klorokuin & 0 & Ada perbedaan \\
& AM 1 & 0 & Ada perbedaan \\
& AM 2 & 0 & Ada perbedaan \\
& AM 3 & 0 & Ada perbedaan \\
& AM 4 & 0 & Ada perbedaan \\
& Kontrol positif & 0 & Ada perbedaan \\
Klorokuin & AM 1 & 0 & Ada perbedaan \\
& AM 2 & 0 & Ada perbedaan \\
& AM 3 & 0 & Ada perbedaan \\
& AM 4 & 0,003 & Ada perbedaan \\
\hline
\end{tabular}

Keterangan:

$\mathrm{p}$ adalah signifikansi, jika $\mathrm{p}<0,05$ artinya ada perbedaan; $\mathrm{p}>0,05$ artinya tidak ada perbedaan

Kontrol positif : infeksi $P$. berghei tanpa terapi

Klorokuin : : pemberian Klorokuin 5,71 mg/kg BB

AM 1 : pemberian terapi ekstrak daun bunga Matahari dosis 0,05 mg/kg BB dan Anting-anting dosis $0,05 \mathrm{mg} / \mathrm{kg} \mathrm{BB}$

AM 2

: pemberian terapi ekstrak daun bunga Matahari dosis 0,5 mg/kg BB dan Anting-anting dosis $0,5 \mathrm{mg} / \mathrm{kg} \mathrm{BB}$

AM 3

: pemberian terapi ekstrak daun bunga Matahari dosis $5 \mathrm{mg} / \mathrm{kg}$ BB dan Anting-anting dosis 5 $\mathrm{mg} / \mathrm{kg} \mathrm{BB}$

AM 4

: pemberian terapi ekstrak daun bunga Matahari dosis $50 \mathrm{mg} / \mathrm{kg}$ BB dan Anting-anting dosis 50 $\mathrm{mg} / \mathrm{kg} \mathrm{BB}$

Berdasarkan Tabel 5, hasil analisis statistika kelompok kontrol positif dibandingkan kelompok perlakuan Klorokuin, AM 1, AM 2, AM 3 dan AM 4 menunjukkan adanya perbedaan yang bermakna ( $\mathrm{p}<$ 0,05) baik perlakuan Klorokuin, AM 1, AM 2, AM 3 dan AM 4 terhadap kontrol positif. Hal ini menunjukkan adanya penghambatan pertumbuhan Plasmodium berghei terhadap dosis terapi kombinasi ekstrak yang diberikan ke hewan uji mencit. Untuk hasil analisis statistika kelompok Klorokuin dibandingkan kelompok perlakuan AM 1, AM 2, AM 3, dan AM 4 menunjukkan adanya perbedaan bermakna $(p<0,05)$ untuk perlakuan AM 1, AM 2, AM 3, dan AM 4 terhadap Klorokuin. Hal ini menunjukkan penghambatan pertumbuhan Plasmodium berghei yang dihasilkan oleh kelompok Klorokuin adalah lebih baik dibandingkan dengan penghambatan pertumbuhan Plasmodium berghei yang dihasilkan oleh perlakuan AM 1, AM 2, AM 3, dan AM 4.

Untuk mengetahui hubungan antara pengaruh dosis terhadap persen penghambatan Plasmodium berghei maka dilakukan uji korelasi dosis. Hasil uji korelasi menunjukkan bahwa dosis korelasi Pearson sebesar 0,980. Nilai tersebut menunjukkan nilai yang mempunyai makna hubungan yang signifikan karena jika nilai pearson correlation dengan $\mathrm{N}=4$ dan taraf signifikan $5 \%$ menunjukkan $>0,950$ bermakna signifikan. Nilai tersebut juga didukung dari hasil signifikansi (P-value) yang $<0,05$ yaitu sebesar 0,020 . Jadi dapat disimpulkan bahwa terdapat hubungan yang signifikan (korelasi bermakna) antara kedua variabel yaitu dosis dan efek persentase penghambatan Plasmodium berghei sehingga dengan kenaikan dosis kombinasi ekstrak diikuti peningkatan efek penghambatan secara bermakna.

\section{KESIMPULAN}

Kombinasi ekstrak etanol $80 \%$ daun bunga Matahari (Helianthus annuus) dan Anting-anting (Acalypha indica Linn) memiliki efek yang sinergis pada uji antimalaria dengan nilai CI sebesar 0,46 $(\mathrm{CI}<1)$ dan nilai $\mathrm{ED}_{50}$ sebesar 1,23 mg/kg BB. 


\section{DAFTAR PUSTAKA}

Chou, T.-C. (2006). Theoretical basis, experimental design, and computerized simulation of synergism and antagonism in drug combination studies. Pharmacological Reviews, 58(3), 621-681.

Coutrier, F. (2008). Propagasi Malaria In Vivo Penggunaan hewan Coba dalam Penelitian Malaria. Jakarta: Pelatihan Propagasi MalariaLembaga Biologi Molekul Eijkman.

Herintsoa, R., Baholy, R. R., Solofoniaina, A. R., Mirindra, R. A., Femanto, R. E. K., Hajatiana, R., ... Jacques, R. (2005). Screening of Plant Extract for Searching Antiplasmodial Activity. In 11th NAPRECA Symposium Book of Proceedings. Madagascar.

Husin, H. (2007). Analisis Faktor Risiko Kejadian Malaria Di Puskesmas Sukamerindu Kecamatan Sungai Serut Kota Bengkulu Propinsi Bengkulu. program Pascasarjana Universitas Diponegoro.

Kee, J. L., Hayes, E. R., \& McCuistion, L. E. (1993). Pharmacology: A nursing process approach. Saunders.

Muti’ah, R., Elok, K. H., \& Ijro'atul B. (2012). Potensi antimalaria ektrak diklorometan daun bunga matahari (Helianthus annuus l.) secara in vivo pada hewan coba. Saintis, 1(2), 1-9.

Ngibad, K. (2018). Uji Kadar Sisa Etanol Dan Abu Total Ekstrak Etanol 80\% Daun Bunga Matahari (Helianthus Annuus) Dan Tanaman Anting-Anting (Acalypha Indica Linn), INARxiv

Rosenthal, P. J. (2003). Antimalarial drug discovery: old and new approaches. Journal of Experimental Biology, 206(21), 3735-3744.

Sukandar, E. Y., Andrajati, R., Sigit, J. I., Adnyana, I. K., \& Setiadi, A. A. P. (n.d.). Kusnandar.(2013). ISO Farmakoterapi, 2.

Susilawati, Matsjeh, S., Pranowo, H. D., \& Anwar, C. (2015). Two isophalerin compounds from ethyl acetate of leave and fruit of mahkota dewa (Phaleria macrocarpa (scheff.) Boerl.) and its antibacterial activity. Indonesian Journal of Chemistry, 15(2), 179-186.

Vincent, K. (2008). Probit analysis. San Francisco: San Francisco State University.

Widawati, M. (2013). The effectiveness of fixative addition on Zodia (Evodia suaveolens S.) and rosemary (Rosmarinus officinalis l.) gel against Aedes aegypti. Health Science Journal Indonesia, 4(2), 103-106. 